The Anarchical Society 


\section{The Anarchical Society}

A Study of Order in World Politics

Second Edition

Hedley Bull

Foreword by Stanley Hoffmann

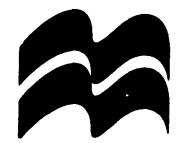


(C) Hedley Bull 1977

Foreword (C) Stanley Hoffmann 1995

Index (C) Mary Bull 1995

All rights reserved. No reproduction, copy or transmission of this publication may be made without written permission.

No paragraph of this publication may be reproduced, copied or transmitted save with written permission or in accordance with the provisions of the Copyright, Designs and Patents Act 1988, or under the terms of any licence permitting limited copying issued by the Copyright Licensing Agency, 90 Tottenham Court Road, London W1P 9HE.

Any person who does any unauthorised act in relation to this publication may be liable to criminal prosecution and civil claims for damages.

First edition 1977

Reprinted 15 times

Second edition 1995

Published by

MACMILLAN PRESS LTD

Houndmills, Basingstoke, Hampshire RG21 2XS

and London

Companies and representatives

throughout the world

ISBN 978-0-333-63822-4

ISBN 978-1-349-24028-9 (eBook)

DOI 10.1007/978-1-349-24028-9

A catalogue record for this book is available from the British Library.

$\begin{array}{llllll}10 & 9 & 8 & 7 & 6 & 5\end{array}$

$\begin{array}{lllllll}04 & 03 & 02 & 01 & 00 & 99 & 98\end{array}$

Copy-edited and typeset by Povey-Edmondson

Okehampton and Rochdale, England 


\section{Contents}

Foreword to the Second Edition by Stanley Hoffmann vii

Preface xiii

Introduction $\quad \mathrm{xV}$

Part 1 The Nature of Order in World Politics 1

1 The Concept of Order in World Politics 3

2 Does Order Exist in World Politics? 22

3 How is Order Maintained in World Politics? 51

4 Order versus Justice in World Politics 74

Part 2 Order in the Contemporary International System 95

5 The Balance of Power and International Order 97

6 International Law and International Order 122

7 Diplomacy and International Order 156

8 War and International Order 178

9 The Great Powers and International Order 194

Part 3 Alternative Paths to World Order 223

10 Alternatives to the Contemporary States System 225

11 The Decline of the States System? 248

12 The Obsolescence of the States System? 272

13 The Reform of the States System? 286

14 Conclusion 307

Notes and References $\quad 309$

$\begin{array}{ll}\text { Index } & 321\end{array}$ 
For Emily, Martha and Jeremy 


\section{Foreword: Revisiting 'The Anarchical Society'}

Stanley Hoffmann

The Anarchical Society is widely recognised today as a classic of the literature on international relations on account not only of its content but also its lucid and crisp prose. It is also seen as the most masterful work in what is called the British school of international relations, or the British approach to international relations (with his dislike of pomposity, Bull would have shied away from the word 'school'). This approach derives its originality from its view of international relations as a complex set of relations among states that form an international society, and not simply a 'system of states'.

We may ask ourselves why so important a book did not receive the recognition it deserved on initial publication in 1977 particularly in the United States - the country where the attempt to develop a discipline of international relations distinct from diplomatic history and international law has gone farthest. The answer is that its 'Britishness' did not fit with the prevailing American approaches. The emphasis on society (however anarchical) seemed strange to realists who, around Hans Morgenthau, studied international relations from the perspective of power-seeking and competing states, or to neo-realists who, following Kenneth Waltz, focused on the effects of the distribution of power in the international system on the inevitable contests of states. For realists and neo-realists, whatever order exists in this endless 'state of war' results from the states' attempts to organise ever-shifting balances of power. Bull devotes a chapter to these, but does not assume that they constitute the alpha and omega of interstate order. However, his book did not satisfy the champions of the other (and older) American approach to international relations - the idealism which, in the spirit of Woodrow Wilson, wishes to reform and to moralise, and sometimes 
even to transcend, the system of states; looks at war and balances of power with dismay, and at diplomacy with distrust; and invests hope in effective and authoritative international institutions. Bull's work, for all its emphasis on common rules, institutions and interests, is too firmly anti-utopian, too closely tied to the system of sovereign states - to what it is now a cliché to call the Westphalian system - to please those for whom states are the problem, not the solution, in so far as order is concerned. Bull's work was too 'Grotian' for the Machiavellians and the Hobbesians, too statist for the Kantians and the cosmopolitans.

Some two-and-a-half decades after its publication, we can judge more serenely the significance of a book which does not constitute the author's last word, and from which Bull may have departed even more if he had not died so prematurely. I will discuss here its importance in two respects: first, as a general approach to international relations, and second, as a way of understanding the present international system.

As a general approach, The Anarchical Society draws our attention to 'the element of co-operation and regulated intercourse among states'. Bull tells us, on the one hand, that every international system can be analysed in such terms (even the Cold War's bipolar system, about which his cool reasonableness proved entirely right); but on the other hand he carefully reminds us that in the international system there is also 'the element of war and struggle for power among states', as well as 'the element of transnational solidarity and conflict, cutting across the divisions among states'. How important the 'interstate society' aspect is, he does not prejudge: it is a matter for empirical investigation. A comparison with Waltz is instructive. Both accept the 'anarchy framework': international relations is the politics of autonomous states, without a common superior. It is the domain of self-help. Both therefore stress the importance of the distribution of power, and particularly of the distinction between the great powers and the lesser ones. (Bull goes on to a distinction of the types of great power behaviour in their spheres of influence.) But Bull's approach is richer. Concerned almost exclusively with the 'state of war', Waltz, in discussing the international system, does not go beyond a binary classification - bipolar versus multipolar systems. Bull's approach would lead itself to a typology based on how much 'society' there is in each system: the distinction between bipolar and multipolar ones 
would thus lose some of the importance that Waltz, or Raymond Aron, gave to it; and the nature of the relations between the strong and the weak would be seen as largely dependent on how much of a society the system is, on the character of its rules and on the content of the states' common interests.

Indeed, when he examines the interaction among states, Bull is interested in things other than the relations of power: common concerns, rules and institutions. This allows him to examine wars not only as the frequent outcomes of power clashes, but also as possible instruments of order, aimed at curbing the ambitions and excesses of trouble-makers: after all, limited wars were a tool for the balancing of power. It also allows him to examine patterns of order that are neither the balance of power nor war: diplomacy and international law.

This approach has two great merits. It reintroduces into the study of the international system three factors left out by Waltz's own reductionism: transnational ideas, which can generate common norms and interests, international institutions, and interdependence (how states 'perform' self-help: co-operatively, unilaterally, or conflictually, depends to a considerable extent on their degree of interdependence). Also, it draws our attention to the relationship between the interactions among states on the one hand, and their nature and their own institutions on the other. In other words, it looks not merely at the distribution of power among the units, but also at the units themselves. The scope of international society (as compared with transnational society) depends on the ratio of free enterprise versus government regulation within the units' political systems. The intensity or depth of international society depends on how much the units have in common. The substance or content of international society depends on the dominant ideas, ideologies or cultures.

This does not mean that Bull's broad and sweeping outline is without ambiguities or problems. Bull, in his discussion of order, states that it assumes 'a sense of common interests in the elementary goals of social life': order thus seems to belong in, and to emerge from, his 'element of society'. But a pattern such as the balance of power can - when it is a product of mechanical, self-interested moves - be part of the 'state of war', just as it can be part of 'society' when it corresponds to a sense of common concerns, and is deliberately 'contrived'; it can be a Hobbesian or a Grotian 
phenomenon. The two aspects of interstate relations - state of war and international society - are hard to distinguish, both because the 'anarchy problematique' does not mean a constant war of all against all - a convergence on co-operation may result from the calculations of self-help, a point made, also in the 1970s, by the socalled neo-liberal institutionalists - and because, conversely, many features of international society are fragile, and can be undermined when those calculations change.

Bull is not explicit enough in analysing the relations between power and the common rules and institutions of international society (although his rather merciless discussion of order versus justice, and particularly of human rights, contains tentative answers). Nor does he go behind the fuzzy notion of common interests: where do they come from (external imperatives? domestic pressures?) and how do they become binding? Above all, in this book, he did not tell us enough about the formation of international society. We need to know more about its origins. These can be both the patterns of interdependence, and the state of war, which often led to the coercive inclusion into the network of rules and institutions of entities previously left out. We need to know more about the mechanisms of international society: since the diffusion of ideas, technology and goods operates through the units, one must study particularly the effects (and different styles) of hegemonic power. We need to know more about the material underpinnings of international society, or about the respective roles of common values or cultures, and of material factors. Bull puts a strong emphasis on cultural cohesion, but historically it often turned out to be brittle and easily destroyed by the 'state of war'. The variations in the ratio of society to state of war, depending on the period, the region of the world, and the issues, are another element that the book, given its generality, does not cover adequately. Bull's approach leads one to asking such questions, and he himself was beginning to answer some of them at the end of his life.

The Anarchical Society can also be seen as an approach to understanding the contemporary international system - a system in which economic interdependence is compelling, where the network of common rules and institutions is dense, where the utility of force has decreased both because of the nuclear danger and because of the irrelevance of war to many of the conflicts economic inter- 
dependence breeds. It is also a world in which the states remain the central actors, and where the diversity of cultures (even if it is not seen as leading to a 'war of civilisations') puts into question the solidity of international society and often challenges its rules. The co-operation of self-interested actors that the theorists of 'international regimes' have explored is a reality for which Bull's work provides a framework.

Nevertheless, here too, question marks abound. First, we find, today, factors Bull did not foresee or integrate into his analysis. There is little in his book about the economic dimensions of international relations (here, he is closer to the realists than to many of the eighteenth-, nineteenth- and twentieth-century liberals); and yet we have witnessed the formation not only of an interstate economic society but also of a transnational world economy, in which private groups and individuals are the actors, and where, thanks to the revolution in communications, decisions are taken under no central political and few national political controls which can overwhelm the resources available to states, and constrain their theoretical sovereignty. It is impossible now to separate as rigorously as Bull did the 'transnational' from the 'international' elements of world politics and of order. Moreover, the problem today is not the hypothetical and elusive world state, or even the deliberate reform of the state system; it is the weakness of so many states, racked and wrecked by ethnic or religious conflicts, inadequate institutions and resources, lack of legitimacy, etc. In a sense, all theorists of international relations have taken for granted the notion of a 'system of states' - in conflict or in cooperation. The dichotomy in their minds has been: systems of several states versus imperial systems. But what happens when the number of failed or disintegrating states increases faster, by far, than the capacity of international society to deal with the resulting chaos? Its rules and institutions are inadequate, and the states' common interest tends to be defined as short-term prudence and avoidance of involvement.

The questions to which the study of the present, post-Cold War, system leads one inevitably are questions Bull left unanswered. How much can society actually flourish in an anarchic milieu? Can the factors of sociability prevail over the antagonisms that exist both in the system of states and in the transnational sphere - or under what conditions? Will the importance of economic interdependence in 
both these realms 'spill over' into, and reduce, the domain of conflict, or will they simply coexist - or else will the conflicts erode society? Can a global international system without a common culture be a genuine and strong society, even if there are dense networks of rules and institutions? What happens to world order when the states challenge it through internal violence and weakness as well as through their customary external violence and aggressiveness, and when transnational society's own rules and institutions create more turbulence than order? Again, these are questions that come straight out of Bull's approach. They could provide students of international relations with a research agenda whose very richness shows the usefulness of the paradigm put forward in this remarkable book - not only for further empirical scrutiny of world politics, but also for normative reflections on the possibility of introducing more ethical concerns into the practices of actors on the world stage, a vast and difficult subject that Bull refused to confront in this 'purely intellectual' inquiry. Next to this agenda, and however sketchy Bull's account of international society may appear, all the competing paradigms look like dead-ends, or like short and narrow paths. 


\section{Preface}

In this book I have sought to expound systematically a view of international society and international order that I have stated only in piecemeal fashion elsewhere.

It owes a lot to my former colleagues in the International Relations Department of the London School of Economics, and especially to C. A.W. Manning. It has benefited greatly from the discussions of the British Committee on the Theory of International Politics, in which I have taken part for some years. I owe a profound debt to Martin Wight, who first demonstrated to me that International Relations could be made a subject, and whose work in this field, to use one of his own metaphors, stands out like Roman masonry in a London suburb. His writings, still inadequately published and recognised, are a constant inspiration.

At some points in the argument I draw on the ideas of my Oxford teacher, H. L. A. Hart. In several chapters I dispute the views of my friend Richard A. Falk of Princeton. I believe, however, that his is one of the most significant points of departure in the study of world politics today, and the attention I devote to refuting him should be taken as a compliment. I am particularly grateful to my friend and colleague, Professor J. D. B. Miller, for his criticism and encouragement.

This book is the product neither of refined theoretical techniques nor of any particularly recondite historical research. When still an undergraduate I was very impressed (I now think too impressed) by the dictum of Samuel Alexander, the author of Space, Time and Deity (London: Macmillan, 1920) that 'thinking is also research'. My book reflects the limitations of an attempt to deal with a large and complex subject simply by thinking it through.

An earlier version of Chapter 4 appeared as 'Order vs Justice in International Society' in Political Studies, vol. xix, no. 3 (September 1971). An earlier version of Chapter 8 appeared as 'War and International Order', in The Bases of International Order: Essays in Honour of C.A.W. Manning, ed. Alan James (Oxford University 
xiv Preface

Press, 1973). I am grateful to the publishers for permission to reproduce passages from these essays.

My greatest intellectual debt is to John Anderson, Professor of Philosophy in the University of Sydney from 1927 to 1958, a greater man than many who are more famous. He had little to say directly about the matters discussed in this book, but the impact of his mind and his example has been the deepest factor in shaping the outlook of many of us whom he taught.

HEDLEY BULL 


\section{Introduction}

This book is an inquiry into the nature of order in world politics, and in particular into the society of sovereign states, through which such order as exists in world politics is now maintained. I have sought answers to three basic questions:

(i) What is order in world politics?

(ii) How is order maintained within the present system of sovereign states?

(iii) Does the system of sovereign states still provide a viable path to world order?

The three parts of the book explore, in succession, these three questions.

It will be helpful if, at the outset, I indicate the basic elements in my approach to this subject. First, I am concerned in this book not with the whole of world politics but with one element in it: order. Sometimes when we speak of world order (or of the world order) what we have in mind is the totality of relationships among states, the international political system as a whole. Here, by contrast, I am thinking of order as a quality that may or may not obtain in international politics at any one time or place, or that may be present to a greater or lesser degree: order as opposed to disorder.

Of course, the element of disorder looms as large or larger in world politics than the element of order. Indeed, it is sometimes held (mistakenly, as I shall argue) that there is no such thing as order in world politics at all, and that we can speak of international order or of world order only as some future, desirable state of affairs which we should strive to bring about but which does not exist at present and has not existed in the past. But while it is important to remember that order is at best only one element in world politics, it is upon this element that I wish to focus attention. Thus when, in Part 2, I consider such institutions of the society of states as the balance of power, international law, diplomacy, war and the great powers, it is their functions in relation to order that I seek to explore, not the place they occupy in the international political system as a whole. 
Second, order in this study is defined (in Chapter 1) as an actual or possible situation or state of affairs, not as a value, goal or objective. Thus it is not to be assumed that order, as it is discussed in this study, is a desirable goal, still less that it is an overriding one. To say that such and such an institution or course of action helps to sustain order in world politics is not to recommend that that institution should be preserved or that course of action followed.

Of course, in common with most men I do attach value to order. If I did not think of order in world politics as a desirable objective, I should not have thought it worthwhile to attempt this study of it. Indeed, it is doubtful whether any serious theory of political ends or values fails to attach some value to order in human relationships.

But, as I argue in Chapter 4, order is not the only value in relation to which international conduct may be shaped, and is not necessarily an overriding value. One of the themes of the present time, for example, is the clash between the preoccupation of the rich industrial states with order (or rather with a form of order that embodies their preferred values) and the preoccupation of poor and non-industrial states with just change. Similarly, we often hear that order in international politics should be subordinated to freedom or liberty - the coalition against Napoleon, for example, saw itself as fighting for the liberties of European nations against a system that provided order but extinguished these liberties, and today it is often said that within the American and Soviet spheres of influence order is imposed at the expense of the freedom or independence of small states.

To speak of order as if it were an overriding value, therefore, would be to beg the question of the relationship between order and other goals, and this I do not wish to do. A study of justice in world politics, which may be envisaged as a companion volume to the present one, might yield some very different perspectives from those that are expressed here. I am not unaware of these perspectives or unsympathetic to them. But this is a study of order in world politics, and not of justice. I do, in the course of this work, consider how order in world politics is related to demands for justice, and I discuss the extent to which demands for just change have to be satisfied if order in world politics is to obtain. But these excursions into the theory of justice are undertaken only because they are essential to the treatment of order.

Third, I have sought to confine my inquiry into order in world politics to enduring issues of human political structure or institu- 
tions, and to avoid consideration of the substantive issues of world politics at the present time. It is often said, sometimes correctly, that the prospects for international order depend on the outcome of some substantive question of the day - as, at present, the control of strategic nuclear weapons, or the development of détente between the United States and the Soviet Union, or the containment of the Arab-Israeli dispute, or the avoidance of a world depression, or the reform of the international monetary system, or the limitation of population growth, or the redistribution of the world's food supply. But whatever the substantive issues of the day may be, they have to be dealt with in the context of the existing political structure of the world, and it is in relation to this political structure, and alternatives to it, that I have sought answers to the three basic questions I have posed about order.

Fourth, the approach to order in world politics that is developed here is one that does not place primary emphasis upon international law or international organisation, and which, indeed, treats order as something that can exist and has existed independently of both. Order, it is contended here, does depend for its maintenance upon rules, and in the modern international system (by contrast with some other international systems) a major role in the maintenance of order has been played by those rules which have the status of international law. But to account for the existence of international order we have to acknowledge the place of rules that do not have the status of law. We have also to recognise that forms of international order might exist in the future, and have existed in the past, without rules of international law. It is, I believe, one of the defects of our present understanding of world politics that it does not bring together into common focus those rules of order or coexistence that can be derived from international law and those rules that cannot, but belong rather to the sphere of international politics.

Similarly, the approach followed here does not place major emphasis upon international organisations such as the United Nations and its specialised agencies, and the various regional international organisations. Of course, the part played by these organisations in the maintenance of order in contemporary world politics is an important one, and this is acknowledged at various points in the argument. But to find the basic causes of such order as exists in world politics, one must look not to the League of Nations, 
the United Nations and such bodies, but to institutions of international society that arose before these international organisations were established, and that would continue to operate (albeit in a different mode) even if these organisations did not exist.

Even the part that is in fact played by the United Nations and other international organisations is best understood not in terms of the official objectives and aspirations of these organisations themselves, or of the hopes commonly placed in them, but in terms of the contribution they make to the working of more basic institutions. It is for this reason that such references as are made to the United Nations and such bodies appear in the chapters dealing with the balance of power, international law, diplomacy, the role of the great powers, and war. It is these latter that are the effective institutions of international society; the League and the United Nations, as Martin Wight once argued, are best seen as pseudoinstitutions. I have also been influenced by the feeling that the United Nations, because of the great mass of documentation it engenders, has been overstudied, and that this tends to deflect scholarly attention away from sources of international order that are more fundamental.

Finally, my purpose in writing this book is not to prescribe solutions or to canvass the merits of any particular vision of world order or any particular path that might lead to it. My purpose, or at least my conscious purpose, is the purely intellectual one of inquiring into the subject and following the argument wherever it might lead.

Of course, I do not wish to imply anything so absurd as that this study is 'value-free'. A study of this kind that did not derive from moral and political premises of some kind would be impossible, and, if it were possible, it would be sterile. What is important in an academic inquiry into politics is not to exclude value-laden premises, but to subject these premises to investigation and criticism, to treat the raising of moral and political issues as part of the inquiry. I am no more capable than anyone else of being detached about a subject such as this. But I believe in the value of attempting to be detached or disinterested, and it is clear to me that some approaches to the study of world politics are more detached or disinterested than others. I also believe that inquiry has its own morality, and is necessarily subversive of political institutions and movements of all kinds, good as well as bad. 